\title{
Deplete Locally, Impact Globally: Environmental History of Shore- Whaling in Barbados, W.I.
}

\author{
Aldemaro Romero*, $^{*}$ and Joel E. Creswell ${ }^{2}$ \\ ${ }^{I}$ Southern Illinois University Edwardsville, College of Arts and Sciences, Edwardsville, IL 62026, USA \\ ${ }^{2}$ University of Wisconsin - Madison, Environmental Chemistry \& Technology Program, 660 North Park Street, Madison, \\ WI 53706-1484, USA
}

\begin{abstract}
We give a detailed history of the exploitation of marine mammals in Barbados, which focused almost exclusively on humpback whales (Megaptera novaeangliae). We have reconstructed this history to better understand the impacts of human activities on the marine environment. Based on historical data, we demonstrate that whaling was a marginal activity financed by local elites who found it easy to transfer labor and tools from agricultural activities to shorewhaling. In spite of its marginal status, this activity not only depleted the local population of whales in a relatively short period of time, it also contributed to the species' global decline. Today, humpbacks can be considered locally absent. Barbados, like other former British colonies, exploited marine mammals through shore-whaling, unlike many Latin American nations, which pursued dolphin fisheries. Barbadian shore-whaling, like many other marine mammal exploitation practices elsewhere in the Caribbean, was heavily influenced by industrialized nations. This history provides important clues for whale management and recovery.
\end{abstract}

Keywords: Whaling, humpback whales, Megaptera novaeangliae, population depletion, environmental history, Barbados, Caribbean.

\section{INTRODUCTION}

There is an increasing interest in approaching conservation biology from historical perspective [1-3]. Because most neoextinctions and population depletions can be attributed directly or indirectly to humans [4-6], the study of the impacts of human behavior and human social organization as they relate to the environment can help us better understand these phenomena. This understanding, in turn, may be used to establish more effective conservation policies, particularly in developing nations, where many threatened species are not well protected.

The historical approach has been useful in elucidating the effects of human overexploitation on marine species of commercial value as far back as almost 500 YBP (years before the present). While the use of molecular techniques to estimate historical population sizes has been attempted for marine mammals (e.g. [7]), and yields valuable information, historical data, when available, represent the only direct source of information for understanding the impact of human activities on a species $[5,8]$.

Organized commercial whaling and dolphin fisheries have existed in the southern Caribbean for more than two centuries $[9,10]$. Although whaling is currently a minor activity in the Caribbean, an increasing number of Caribbean countries have joined the International Whaling Commission (IWC) in recent years, and have supported the resumption of commercial whaling. St. Vincent and the Grenadines has

*Address correspondence to this author at the Southern Illinois University Edwardsville, College of Arts and Sciences, Edwardsville, IL 62026, USA; Tel: (618) 650-5047; Fax: (618) 650-5050; Email: aromero@ siue.edu lobbied for an increase in its capture quota [11]. In order for informed decisions to be made about whether to increase the intensity of whaling, there is a need for comprehensive, upto-date information on marine mammals in the Caribbean, specifically about the history of their exploitation in each country. Studies similar to this one have shown that past exploitation practices have directly impacted the population status of various species (e.g., [9,12-15]).

\section{MATERIALS AND METHODOLOGY}

Barbados is a small island (430 square $\mathrm{km}$ ) in the southeastern Caribbean, originally inhabited by the Arawak and Carib indigenous groups. It was later visited by the Spanish, Portuguese, and finally the British, who claimed it in 1625 , and made it a major center for sugar production [16].

We visited Barbados in spring, 2002 to compile data and historical narratives from local government records, scientific literature, sightings by reliable observers, and field interviews. In reviewing published reports, we examined all scientific and popular accounts of marine mammals in the area. Given the wide range of publication dates and the nature of many of the sources used for this research, we followed the basic principles of research synthesis [17].

We studied available logbooks of whaling ships that visited Barbadian waters by contacting or visiting major logbook repositories (Appendix). We also investigated archival records (primarily the 'Blue Books', the annual colonial statistical summaries produced by local British government officials, but also Archer [18]) for the 18761910 period, which provided data on whale oil production and the number of boats and crew employed. For years in 
which there are production data from either the Blue Books or Archer [18], but not both, the available number is reported. For years in which production data are reported in both sources, the Blue Books number is used, as it represents exports from the entire island, while Archer's data most likely represent only one whaling station.

For cross-cultural comparisons, we used information on marine mammal fisheries in the wider Caribbean [10,19,20, and references therein].

We obtained firsthand information from local sources and visited local museums and private collections of whaling paraphernalia. We also conducted interviews with local fishers, following the standard questionnaires used in collecting information about the utilization of marine mammals by fishers $[21,22]$.

Because much of the original information on shorewhaling in Barbados was in the form of oil production statistics, we had to estimate the number of whales killed using indirect methods. The most widely accepted method was developed by Mitchell and Reeves [23]. They estimated that humpback whales in the West Indies produced an average of $25 \mathrm{bbl}$ (barrels) of oil ( 1 barrel $=31.5$ American gallons $=26.28$ imperial gallons $\approx 119$ liters). These estimates were later confirmed by a more comprehensive study, using a much larger sample of catches by nineteenth century American pelagic whalers [24], which estimated the average yield from a humpback whale was 24.4 bbl. Mitchell and Reeves further stipulate that, because not every whale that is killed is landed, one must multiply the number of whales landed by 1.86 to estimate the total number of whales killed.

For every year after 1878 , we used the precise whale oil production figures (in gallons) from the 'Blue Books' to calculate the number of whales killed (rounded-up to the nearest integer), using the $25 \mathrm{bbl} / \mathrm{whale}$ factor. These numbers yielded much more complete and precise estimates than were previously available for this area $[15,23]$.

\section{RESULTS}

\section{Historical Account of Human-Marine Mammal Interactions in Barbados}

\section{Pre-Columbian Utilization and Other Early Historical Records}

Despite archaeological evidence from numerous sites in the Caribbean, showing that Amerindians utilized all marine mammal resources at their disposal (e.g., [9,12-14,25]), there is only one pre-Columbian site in Barbados with associated marine mammal remains. They are a sperm whale (Physeter macrocephalus) and unidentified dolphins [26,27]. Given the size and usual habitat of sperm whales, deep water, it is unlikely that Amerindians in Barbados actively hunted them. These remains are most likely of a stranded animal that was opportunistically used by the Amerindians. There is no reliable evidence that manatees ever inhabited Barbados. There is one record of an alleged sighting of a manatee (Trichechus manatus) on the island [28], but this record is untrustworthy, as it is not accompanied by any description, and is not consistent with the historical distribution of this species.
The only historical record of marine mammal utilization in Barbados before active commercial whaling began on the island dates to 1813 . The animal taken was described as a 'Grampus' (Risso's dolphin, Grampus griseus), but the dimensions given, "twenty-two feet six inches in length" $(6.86 \mathrm{~m})$ [28: p. 682] are too big for that species (usually $4 \mathrm{~m}$ in length). According to the above-referenced account 'It was considered too young to afford any oil, and the Negroes used therefore the flesh for culinary purposes'. Most likely the animal in reference was a humpback whale calf (Megaptera novaeangliae) [23].

\section{Yankee Whaling}

Bridgetown, Barbados' capital, was a popular port for Yankee whaling vessels traveling from Europe, Western Africa or eastern South America. A survey of logbooks, journals and other published information about Yankee whaling activities in the wider Caribbean found records of 456 voyages to the West Indies between 1763 and 1919, 248 of which (54.35\%) visited Barbados (Fig. 1).

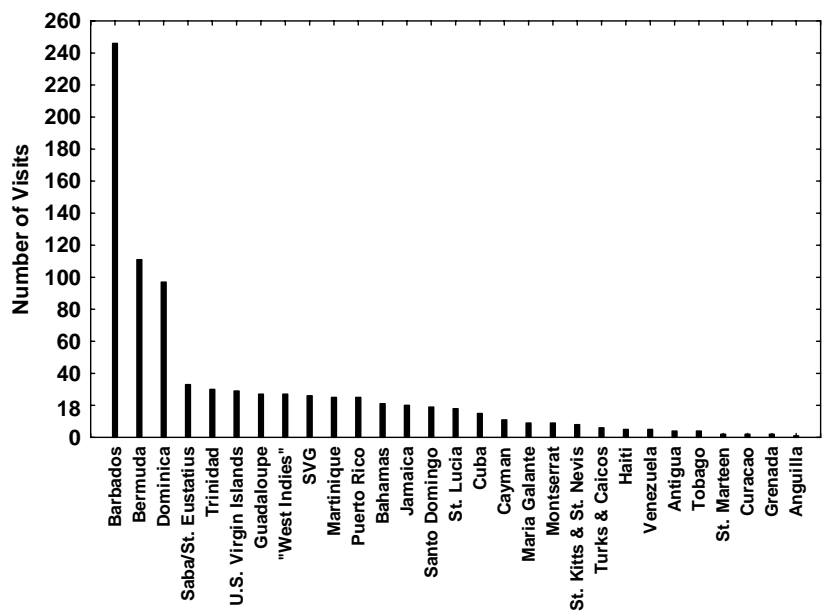

Fig. (1). Number of visits of Yankee whaling vessels to areas in the wider Caribbean ( $\mathrm{SVG}=\mathrm{St}$. Vincent and the Grenadines).

As can be seen from a sample of voyages (Appendix), Yankee whalers in Barbados engaged in whaling and the trans-shipment of whale oil and utilized Barbadian ports for the re-stocking of provisions. This provided ample opportunity for Barbadians to acquire whaling skills directly from Yankee whalers. In fact, locals began joining Yankee whaling ship crews as early as 1765 , to replace crew members who had died or deserted their ships [29,30: p. 52]. In this way, many Barbadians gained the necessary skills to hunt whales [31-34], and applied them to shore-whaling after returning to Barbados.

\section{Shore-Whaling}

The first shore-whaling record from Barbados dates back to 1867. In that year, an unknown local entrepreneur began to whale out of Speightstown [35]. This coastal town was particularly well suited for whaling operations not only because it was located on a migratory route for many whales, but also because it was once an important port, and therefore had shipping infrastructure, which was beneficial to the whalers. 
This first whaling venture was eventually sold to C.H.P. Jordan, a local merchant, who owned it until 1920. The last year this operation captured whales was 1912, when four animals were secured and two were killed but lost. A second shore-whaling operation was established about the same time as Jordan's and was located immediately next to it. Its original ownership is uncertain, but by the time it closed, around 1920, it was owned by another local merchant, Allan O'N. Skinner [sic]. Skinner's enterprise had two boats and employed 14 men [36]. Apparently, all of the workers at this establishment were black $^{1}$ [37]. A third shore-whaling operation, which began in 1869 [34], was located in Holetown, $7 \mathrm{~km}$ south of Speightstown, under the ownership of Alleyne S. Archer [32]. All of these locations are on the west (leeward) coast of Barbados. These areas were frequently visited by humpbacks and had calmer waters than the other parts of the island, making them better suited to the maneuvering of small whaling boats.

All three whaling ventures were operationally very similar. They only targeted humpbacks that visited nearshore waters between January and May. This was the time of the year when most workers involved in sugar cane production and other agricultural activities were less occupied, and it was thus easy to employ them in shorewhaling. March was the month when most whales were captured. Captures were opportunistic, with whale sightings taking place either from shore or from the whaling boats, which sometimes left before dawn in order to reach the area where the whales were expected to be. Whaling gear was stored in shacks at the beach where the 'boiling house' was located. The boats were hung on davits on a jetty. Barbadian whalers employed four 25 to $30 \mathrm{ft}$. (7.62 to $9.14 \mathrm{~m})$ boats, rigged with sails as well as oars and paddles. The oars were used for maximum steering and control when pursuing a whale, and the sails were used at all other times. The boats were equipped with 300 fathoms (ca. $540 \mathrm{~m}$ ) of 'manila whale-line', four 'toggle-irons' (harpoons), three six-foot (1.8 $\mathrm{m}$, of which $1.5 \mathrm{~m}$ was a wooden pole) hand lances with spear-shaped heads, and one breech-loading bomb-gun with five to six explosive bomb lances. Each boat usually had a crew of six to seven, although at times up to 14 people were on board. Each boat usually had one 'officer' (harpooner), one 'boat-steerer' (who also helped with the line once the whale had been struck) and four or more oarsmen [38: 214215]. The men on the boat were paid weekly wages in advance and received a bonus based on the profits generated by captured whales [36].

The crews targeted mother-calf pairs, and approached the whales from behind. They struck the calf first so that they could more easily kill the mother when she came to protect it. If no such pairs were available, they pursued lone adults. After throwing one or two harpoons, they moved close to the animal, shot one or more bomb lances, and threw several hand lances as close as possible to the heart of the animal. Depending upon the effectiveness of their shooting, the animal would die between 10 minutes and twelve hours after being struck, with most dying in about a half hour. Many escaped after being hit. Some crew members of the whaling boats were killed or seriously injured by getting entangled in the ropes and being pulled down by a diving whale. On other

${ }^{1}$ Elmer Jordan, personal communication, 2002 occasions, boats were broken up by the tail of a fighting whale [37,38: 214-215].

Once the whale was dead, men jumped into the water to sew its mouth shut, in order to prevent it from filling with water and sinking. The sewing was done by opening holes into the upper and lower jaws with a sharp blubber-spade and passing a rope through them [37]. Whales were then dragged ashore, alongside a 200 foot (ca. $61 \mathrm{~m}$ ) jetty (in the Speightstown operations) or on the beach (in the Holetown operation) for flensing. In Speightstown, the whale was flensed in water about two fathoms (ca. $3.6 \mathrm{~m}$ ) deep. Although there are reports of sharks attacking whale carcasses during flensing, unlike on other Caribbean islands such as Trinidad [12], the local operators never employed anyone to kill the sharks. In fact, the whalers could reportedly walk through the water in the midst of the frenzied sharks and not be harmed ${ }^{2}$. At least once, a whale that was killed off Barbados was taken to Martinique, where it was boiled and the meat was consumed by locals [37,38: 214-215].

There was often significant competition between the stations in Speightstown over whales. Because the stations were next to each other, they often saw whales at the same time and would race to be the first to strike them. This led to a significant amount of quarreling between the two whaling companies, which sometimes resulted in boats from the two companies ramming each other, and whalers scaring away whales to prevent their competitors from catching them $[39,40]$. Thus, in 1904 , the government passed the Fisheries Regulation Act, which established rules for competition between whaling boats The law included provisions that guaranteed ownership of a whale by the first boat that struck it, and ownership of a mother by the boat that strikes her calf, and vice versa. The law even detailed how profits and expenses were to be split if two boats happened to strike the same whale at the same time [41].

Once an animal was landed and flensed (an operation that took about 24 hours), the blubber was boiled for about 48 hours in copper kettles of the same design as those used to boil sugar cane juice. In fact, the boilers used by the Jordan whaling station in Speightstown were sold to a sugar factory after the station closed. Each adult whale usually yielded between 50 and 60 barrels (bbl) of oil but some produced up to $90 \mathrm{bbl}^{3}$ [35,37,38: pp. $\left.214-215,42,43\right]$.

The oil was used locally as an illuminant or lubricant and was exported to England [43], Canada, ${ }^{4}$ the United States, Trinidad, and Demerara (Guiana) [38: p. 214]. In 1913 the price ranged from 13 to 18 pounds sterling per ton [37]. The bones were ground and used to make fertilizer. The meat was sold locally and 'used as a food by the negroes and is very nourishing' [36,37]. The baleen plates were used to make brooms [36]. In these ways, the entire whale carcass was utilized, although the main generator of profit for the whaling operation was the oil [44].

After the closure of the C.H.P. Jordan station in Speightstown in 1920, rather than being sold or converted to fishing vessels, the two whale boats that remained at that

${ }^{2}$ Elmer Jordan, personal communication, 2002

${ }^{3}$ Elmer Jordan, personal communication, 2002.

${ }^{4}$ Geoffrey O'N. Skinner [sic], personal communication, 2002. 


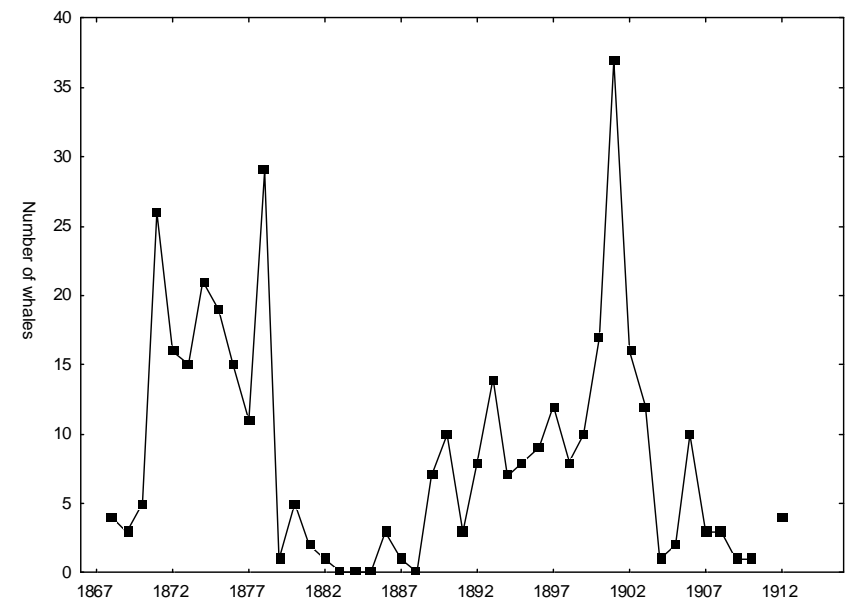

Fig. (2). Total number of whales landed and killed annually, based on data on annual whale oil production from Blue Books and Archer 1881. The number of whales killed is equal to 1.85 times the number of whales captured, following the established method by Mitchell and Reeves 1983.

time were taken to Grenada. Ernest Greaves, the last whaler employed at the station, operated in Grenada, using those boats, from 1920 to 1923 . He found ample whales there, but apparently, 'the tide was too strong' to run under sail, so he sold the boats there and went to work for the Norwegian whale fishery on Glover Island, a small island off Grenada's south coast [14].

\section{Numerical Estimates}

A summary of the landings of humpback whales by the shore whaling industry in Barbados (Fig. 2) shows that there were wide fluctuations over the duration of this industry. The average annual oil production between 1868 and 1912 was 202 barrels per year, and our estimate of the total number of whales landed in the Barbadian shore whaling industry was at least 380. However, given that many more whales were struck than landed, we applied the Mitchell and Reeves [23] correction factor to arrive at a total estimate of 707 whales killed.

Smith and Reeves [45] and Mitchell and Reeves [23] estimated that Yankee Whalers killed 1,617 humpback whales in the Caribbean. This estimate is conservative, as it only based on whales landed between 1866 and 1887. Our search showed that Yankee whalers operated in the Caribbean from 1762 until 1921. The number of humpbacks taken in Trinidad by shore-whaling was over 500 [12], by one estimate, and 489 by another [46]. In Grenada, at least 187 humpbacks were taken [14], in St. Vincent and the Grenadines, either 1,719 [19] or 1887 [47] were taken, and in Barbados, 707 were taken (this paper). The sum of these estimates is 3,113 whales killed in the southeastern Caribbean by shore-whaling operations alone. This figure is conservative since it does not include whales taken for which data are not available. Adding the 3,113 whales killed by shore-whaling operations to the 1,617 killed by Yankee whalers provides a minimum estimate of 4,730 whales killed in a little more than 100 years.

\section{DISCUSSION}

The information presented in this paper has major implications in two areas of conservation biology: (1) cultural patterns of marine mammal exploitation in the Caribbean, and (2) the relationship between whale oil production and the conservation of whales.

Table 1. Comparative analysis of cetacean species taken by Latin American countries and former British colonies in the Caribbean. There is a clear distinction between the two groups of countries with the exception of St. Vincent and the Grenadines where the dolphin fisheries began with a focus on pilot whales, which were also chased by Yankee whalers. St. Vincent and the Grenadines' industry later expanded opportunistically into other smaller species of cetaceans.

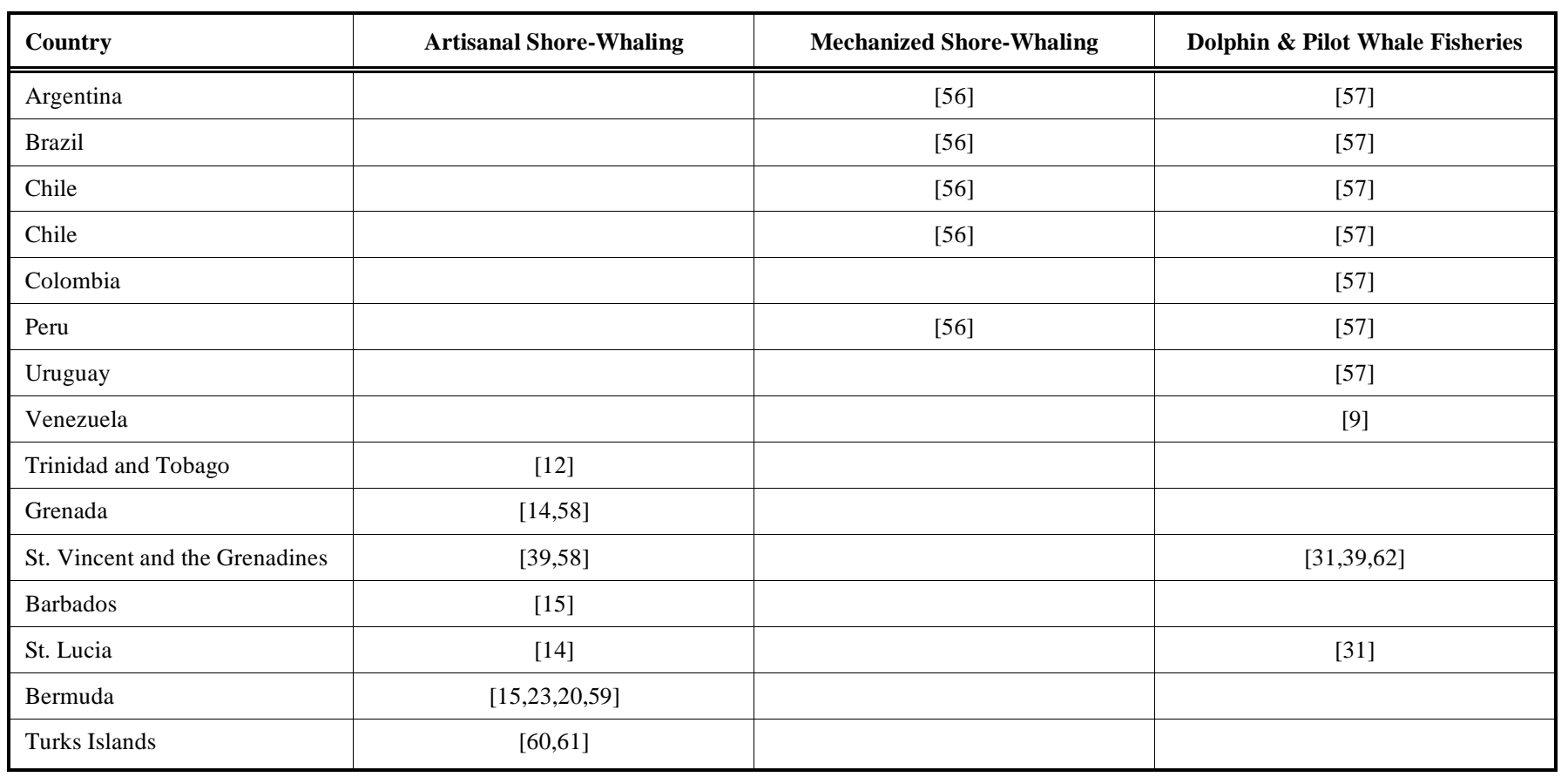




\section{Cultural Patterns of Marine Mammal Exploitation in the Caribbean}

The shore-whaling experience in Barbados was similar to that of Grenada and Trinidad. Grenada followed a comparable trend of increasing production, but on a much shorter time scale than Barbados. Whaling in Grenada took place for only seven years $(1920$ - 1926). The peak in production was in 1925, when 105 whales were landed. In the following year, 72 whales were landed. By 1927, not a single whale was taken, because the population had become too sparse, and the industry was dismantled [14]. Trinidad's first whaling station opened around 1826, and by 1830,14 or 15 whales had been killed. Between 1830 and 1862 between 20 and 35 whales per year were captured. Then, around 1865 , commercial whaling ceased due to a lack of whales [12]. In Trinidad, as in Barbados, local business families owned and operated the whaling operations, but whaling was not their primary source of income. Trinidad, Grenada, and Bermuda, all former British colonies, concentrated on shore whaling of humpbacks. Latin American countries have a different tradition, focused primarily on dolphin fisheries. Only a few Caribbean countries combined shore whaling and dolphin fisheries (Table 1).

In Barbados, as has been reported for other areas in the Caribbean (e.g., [12]), whale meat was consumed largely by African slaves and/or their descendants.

\section{Whale Oil Production and the Conservation of Whales}

During the first three decades of the whaling industry in Barbados, as expected, financial gains increased as whale oil production increased to its peak at the turn of the century (Fig. 3). However, in 1901, that relationship reversed, when the price per barrel dropped below $£ 1$. The fact that the price per barrel remained relatively low after the peak suggests the interplay of two factors: market saturation with whale oil and an increased supply of mineral oil and its derivatives. This same combination of factors contributed to the demise of Trinidad's whaling industry: from the 1870's onward, kerosene was being used as lamp fuel, lard oil was being used as a lubricant, and whale oil was being overproduced, causing its price to plummet [12].

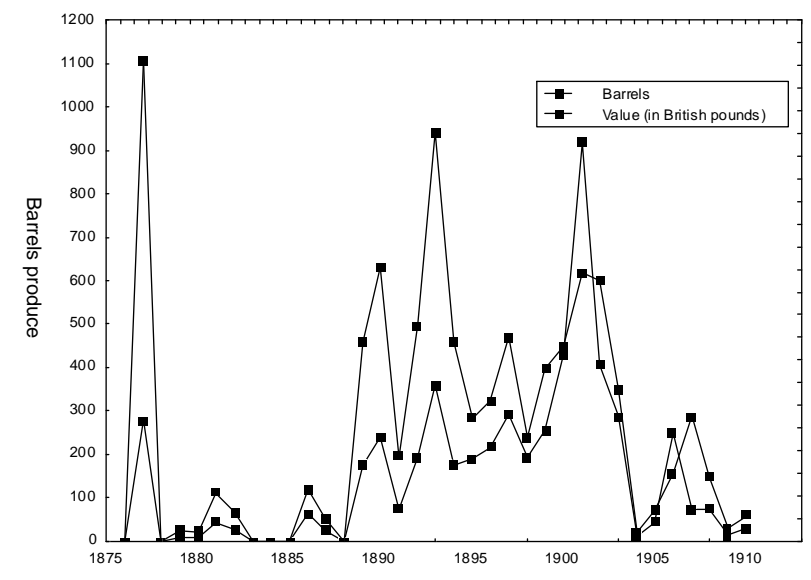

Fig. (3). Total number of barrels of whale oil exported from Barbados and its total value (in British pounds). Based on Blue Book data on annual whale oil production and prices for Barbados.
It was ecology, not economics, however, that triggered the ultimate demise of humpback whaling in Barbados. By all accounts it was the intense competition for whales and their overexploitation that drove these cetaceans to virtual local extinction [35]. Elmer Jordan, a descendant of C.H.P. Jordan, agrees that whaling ceased because the local whale population was depleted. ${ }^{5}$ This depletion is consistent with a well-documented pattern of overkill of large mammals, by humans, in island ecosystems, leading to local extinction [5,6]. The export data support this contention: in 1902, 405 barrels were produced, a sharp drop from the absolute production peak in 1901 of 919 barrels. By 1904, only 12 barrels were produced. Although production increased again in 1906 , to 250 barrels, it never returned to the high levels of the turn of the century, and the industry effectively shut down in 1912. This trend suggests that as the intensity of whaling increased, the local whale population could not recover and was eventually wiped out.

One reasonable explanation for the fluctuations in whale oil production is changes in the intensity of whaling effort in response to sugar prices in the export market. Toward the end of the 1890's, sugar cane prices plummeted, and Barbados entered into an economic recession [48: Chapter 5].

The hypothesis that the whaling industry ended due to the depletion of the whale stock is further supported by the migratory biology of humpbacks in the area. Most whales migrate annually through the Western North Atlantic, from north to south and back, hopping from island to island until they reach their preferred breeding and calving grounds. This means that whales traveling as far south as Barbados would have been at risk from several whaling operations on other islands before even entering Barbadian waters. Thus, the whaling industry in Bequia, which was in operation at the same time as the one in Barbados, may have impacted Barbados' whale stocks. Likewise, we hypothesize that Barbadian whaling was probably influenced by Tobago, Trinidad, and Venezuela's whale stocks, which were depleted even earlier by both shore and Yankee whaling $[9,12]$. Since whalers concentrated on females and their calves, the impact of exploitation on the population was compounded, and may be much greater than previously suspected. Today humpback whales are rare in the southeastern Caribbean, as confirmed not only by our interviews with the local fishers but also by a recent visual and acoustic survey [49].

Barbados' whale fishery, which killed a total of 707 whales, may have had a cumulative negative impact on the overall population of humpbacks in the western North Atlantic, currently home to about 10,000 individuals [50]. This species is classified as "Least Concern" by the World Conservation Union (IUCN) and listed in Appendix I of the Convention on International Trade in Endangered Species (CITES). The fact that local populations of humpbacks were depleted wherever they were heavily exploited, and that individuals of this species show a great deal of site fidelity, suggests that the genetic structure of the North Atlantic humpbacks may be more compartmentalized than was previously assumed. This fractionation is most likely due to

${ }^{5}$ Personal communication, 2002. 
the large number of islands in the Caribbean. If the Caribbean humpback population is as compartmentalized as we now expect it to be, exploitation at the local level, such that allowed by the IWC, near Bequia, may be globally detrimental.

\section{CONCLUSION}

Shore whaling in Barbados was a temporary (18671910), seasonal (from January to May), economically marginal activity. The major industry in Barbados at that time was sugar production. By 1897 , about $£ 10,000,000$ had been invested in sugarcane-processing machinery alone [48: p. 143], while at the peak of the whaling industry, in the 1870 's, the total value of whale oil produced was only $£ 1100$. As on other Caribbean islands under British influence, this activity was financed and operated by local financial elites involved in sugar production. Technology and labor transfer was easy and convenient for these financiers, as they employed the same laborers and some of the same equipment for both operations. Yet the technology employed and the target species have always been influenced by foreign cultural factors. Signs of foreign influence include (1) shore-whaling boats designed after those used by Yankee whalers, (2) target species chosen based on British-colonial preferences, and (3) shore-whaling techniques modeled after those of other British Caribbean islands. Unlike Venezuela, where dolphin fisheries and manatee exploitation were common in pre-Columbian times, or Trinidad and Grenada, where manatee exploitation was common, there was virtually no marine mammal exploitation in Barbados before the advent of foreign whaling in the Caribbean. Thus, foreign influence played a major role in Barbados' whaling industry and attitudes about whales.

\section{ACKNOWLEDGEMENTS}

The following people provided us with first-hand, unpublished information: Mr. Elmer Jordan, Mr. Charles Jordan, Ms. Ina Jordan; Dr. Christopher Parker, Fisheries Division, Barbados; Dr. Julia Horrocks, Biology Department, University of the West Indies, Cave Hill; as well as numerous local fishers. Ms. Karen Solomon provided assistance with materials at the Barbados National Library Service. Aaron Albertson dedicated countless time and energy to securing inter-library loan material. Peter Vaughan, Environmental Studies Program, Macalester College; and Donald Siniff, Department of Ecology, Evolution, and Behavior, University of Minnesota, read JEC's original Honors Thesis on this subject and made valuable suggestions. Shelly Kannada, Arkansas State University, and Andrea Romero, Carleton College, made valuable comments to the MS. This research was generously funded by the Macalester College Environmental Studies Program.

\section{APPENDIX}

Sample of activities by Yankee whalers in Barbadian waters. These records were compiled from logbooks from American whaling vessels. We extracted the basic information from Starbuck [51], Hegarty [52] and Lund [53], all of whom compiled information about 14,864 whaling voyages made by American vessels. For them there are about 5,018 logbooks and private journals in 82 public collections around the world [54]. Many logbooks are unavailable because they are either in private collections or were lost along with their ships. Information was also obtained from Whalemen's Shipping List, published in New Bedford, Massachusetts from 17 March 1843 to 29 December 1914. Explanations: 'sperm' refers to sperm whale oil; bbl = barrels; 'bull' refers to male; Acronyms for libraries where logbooks are deposited: KWM: Kendall Whaling Museum, Sharon, MA; NBFPL: New Bedford Free Public Library, New Bedford, MA (the former recently merged with the latter); NHA: Nantucket Historical Association; ODHS: Old Dartmouth Historical Society, New Bedford, MA; PMS: Peabody Museum at Salem; PPL: Providence Public Library, Providence, RI.

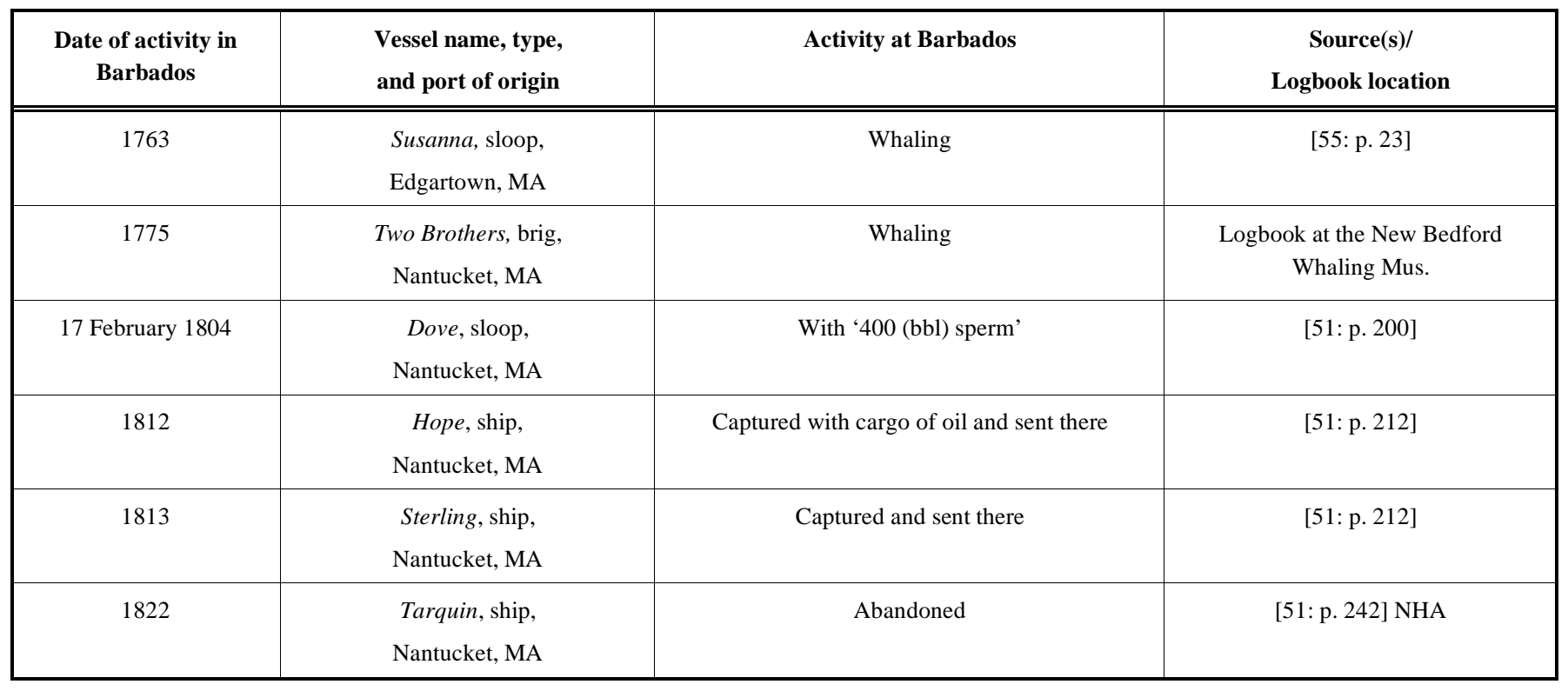


(APPENDIX). Contd.....

\begin{tabular}{|c|c|c|c|}
\hline $\begin{array}{l}\text { Date of activity in } \\
\text { Barbados }\end{array}$ & $\begin{array}{l}\text { Vessel name, type, } \\
\text { and port of origin }\end{array}$ & Activity at Barbados & $\begin{array}{c}\text { Source }(\mathbf{s}) / \\
\text { Logbook location }\end{array}$ \\
\hline 10 February 1840 & $\begin{array}{l}\text { Two Sisters, brig, } \\
\text { Rochester, MA }\end{array}$ & Two humpbacks sighted & {$[34,51:$ p. 356] KWM } \\
\hline 26 January 1853 & $\begin{array}{c}\text { Solon, bark, } \\
\text { Westport, MA }\end{array}$ & Several whales sighted off Bridgetown & {$[34,51:$ p. 496] } \\
\hline February-April 1858 & $\begin{array}{c}\text { Willis, bark, } \\
\text { Mattapoisett, MA }\end{array}$ & Chased humpbacks unsuccessfully & [34,51: p. 555] ODHS \\
\hline 19 March 1859 & $\begin{array}{l}\text { Messenger, ship, } \\
\text { New Bedford, MA }\end{array}$ & Took a $24 \mathrm{bbl}$ bull humpback in Carlisle Bay & [Wood n/d in 34,51: p. 524] PMS \\
\hline 1863 & $\begin{array}{c}\text { Ellen, bark, } \\
\text { Edgartown, MA }\end{array}$ & Sent home $99 \mathrm{bbl}$ of sperm; condemned & {$[51:$ p. 582] } \\
\hline May 1863 & $\begin{array}{l}\text { A.R. Tucker, bark, } \\
\text { New Bedford, MA }\end{array}$ & Struck and lost a humpback while at anchor & {$[23,51:$ p. 580$]$ ODHS } \\
\hline 12-21 May 1863 & $\begin{array}{c}\text { Willis, bark, } \\
\text { Mattapoisett, MA }\end{array}$ & A 55bbl whale was taken 'in port' & {$[23$, Wood n/d in 34,51: p. 588] } \\
\hline 21 June 1864 & $\begin{array}{c}\text { Willis, bark, } \\
\text { Mattapoisett, MA }\end{array}$ & 1 humpback taken & $\begin{array}{c}\text { [34,51: 588] Whalemen's Shipment } \\
\text { List, 22(16):21 }\end{array}$ \\
\hline 12 February 1864 & $\begin{array}{c}\text { Mattapoissett, brig, } \\
\text { Westport, MA }\end{array}$ & One whale seen & [51: p. 588] ODHS \\
\hline June 1866 & $\begin{array}{c}\text { Solon, bark, } \\
\text { New Bedford, MA }\end{array}$ & Wrecked and condemned & [51: p. 604] NBFPL \\
\hline June 1866 & $\begin{array}{c}\text { Willis, bark, } \\
\text { New Bedford, MA }\end{array}$ & 70bbl obtained 'while at anchor' & $\begin{array}{l}\text { [51: p. 606] Whalemen's Shipment } \\
\text { List 24(18):21, June } 1864\end{array}$ \\
\hline March 1867 & $\begin{array}{c}\text { Roscius, bark, } \\
\text { New Bedford, MA }\end{array}$ & Condemned & [51:p. 612] \\
\hline October 1870 & $\begin{array}{l}\text { Pocahontas, brig, } \\
\text { Marion, MA }\end{array}$ & Condemned; sent home $150 \mathrm{bbl}$ sperm & {$[51:$ p. 626] } \\
\hline April 1873 & $\begin{array}{c}\text { Geo. J. Jones, brig, } \\
\text { Fairhaven, MA }\end{array}$ & Condemned; sent home $278 \mathrm{bbl}$ sperm & [51: p. 644] \\
\hline 1874 & $\begin{array}{l}\text { Eschol, brig, } \\
\text { Beverly, MA }\end{array}$ & Condemned & [38,51: p. 646] KWM \\
\hline 14 December 1874 & $\begin{array}{c}\text { Myra, brig, } \\
\text { Sag Harbor, NY }\end{array}$ & $\begin{array}{l}\text { Condemned; sent home } 430 \mathrm{bbl} \text { sperm, } 590 \mathrm{bbl} \\
\text { whale, } 700 \mathrm{lbs} \text { bone }\end{array}$ & {$[51:$ p. 642] } \\
\hline March-April 1880 & $\begin{array}{l}\text { Clara L. Sparks, schooner } \\
\text { Provincetown, MA }\end{array}$ & $\begin{array}{l}\text { Noted several whaling ships humpbacking there. } \\
\text { At least one whale landed. Off-loaded oil. }\end{array}$ & [23] PPL \\
\hline 29 December 1883 & $\begin{array}{l}\text { Union, schooner, } \\
\text { New Bedford, MA }\end{array}$ & Lost. & [52: p. 15] ODHS \\
\hline 15 May 1884 & $\begin{array}{c}\text { Pioneer, bark, } \\
\text { New Bedford, MA }\end{array}$ & Condemned. & {$[52:$ p. 10$]$} \\
\hline June 1912 & $\begin{array}{c}\text { Grace, brig, } \\
\text { New Bedford, MA }\end{array}$ & Off-loaded oil. & [30: pp. 1-3] \\
\hline 19 April 1920 & $\begin{array}{l}\text { A.V.S. Woodruff, schooner, } \\
\text { New Bedford, MA }\end{array}$ & Lost. & [52: p. 45] \\
\hline
\end{tabular}

\section{REFERENCES}

[1] Meine C. It's about time: conservation biology and history. Conserv Biol 1999; 13: 1-3.

[2] Jackson JBC. What was natural in the coastal oceans? P Natl Acad Sci USA 2001; 98: 5411-8.
[3] Romero A. Death and taxes: the case of the depletion of pearl oyster beds in sixteenth-century Venezuela. Conserv Biol 2003; 17: $1-12$.

[4] Burney DA, Flannery TF. Fifty millennia of catastrophic extinctions after human contact. Trends Ecol Evol 2005; 20: 395401 . 
[5] Diamond JM. In: Martin PS, Klein RG, Eds. Quaternary extinctions: A prehistoric revolution. Tucson: The University of Arizona Press 1984; pp. 824-62.

[6] Koch PL, Barnosky AD. Late quaternary extinctions: state of the Debate. Annu Rev Ecol Evol S 2006; 37: 215-50.

[7] Roman J, Palumbi SR. Whales before whaling in the North Atlantic. Science 2003; 301: 508-10.

[8] Romero A, Kannada SD. Comment on "Genetic analysis of 16thcentury whale bones prompts a revision of the impact of Basque whaling on right and bowhead whales in the western North Atlantic". Can J Zool 2006; 84: 1059-65.

[9] Romero A, Agudo AI, Green SM. Exploitation of cetaceans in Venezuela. Rep Int Whal Commn 1997; 47: 735-46.

[10] Romero A, Creswell JE. In: Romero A, West S, Eds. Environmental Issues in Latin America and the Caribbean. New York: Springer 2005; pp. 3-20.

[11] Cyranoski D. Whaling divisions deepen as Japan pushes for credibility. Nature 2005; 435: 861.

[12] Romero A, Baker R, Creswell JE, Singh A, McKie A, Manna M. Environmental history of marine mammal exploitation in Trinidad and Tobago, W.I., and its ecological impact. Environ Hist 2002; 8: 255-74.

[13] Romero A, Hayford KT, Romero A, Romero J. The marine mammals of Grenada, W.I., and their conservation status. Mammalia 2002; 66: 479-94.

[14] Romero A, Hayford K. Past and present utilisation of marine mammals in Grenada, West Indies. J Cetacean Res Manage 2000; 2: 223-6.

[15] Reeves RR, Smith TD. Historical catches of humpback whales in the North Atlantic Ocean: an overview of sources. J Cetacean Res Manage 2002; 4: 219-34.

[16] Tree R. A history of Barbados. London: Granada Publishing 1972.

[17] Cooper H, Hedges LV. The handbook of research synthesis. New York: Russel Sage Foundation 1994.

[18] Archer AS. Sea-Fishing in Barbadoes. The Field, The Country Gentleman's Newspaper 1881; 1054 (22 Oct): 592.

[19] Kannada SD. Environmental history and current practices of marine mammal exploitation in St. Vincent and the Grenadines, W. I. MS Thesis. Jonesboro, AR: Arkansas State University 2006.

[20] Romero A. "More private gain than public good": whale and ambergris exploitation in seventeenth-century Bermuda. Bermud J Archaeol Marit Hist 2006; 17: 5-27.

[21] Dolar MLL, Leatherwood S, Wood C, Alava MNR, Hill C, Aragones LV Directed Fisheries for cetaceans in the Philippines. Rep Int Whal Commn 1994; 44: 439-49.

[22] Aragones LV, Jefferson TA, Marsh H. Marine mammal survey techniques applicable in developing countries. Asian Mar Biol 1997; 14: 15-39.

[23] Mitchell E, Reeves RR. Catch history, abundance, and present status of northwest Atlantic humpback whales. Rep Int Whal Commn 1983; Special Issue 5: 153-212.

[24] Best PB. Estimates of the landed catch of right (and other whalebone) whales in the American fishery, 1805-1909. Fish BNOAA 1987 ; 85 : 403-18.

[25] Lefebvre LW, O'Shea TJ, Rathbun GB, Best RC. In: Woods CA, Ed. Biogeography of the West Indies: Past, Present, and Future. Gainesville: Sandhill Crane Press 1989; pp. 567-609.

[26] Ray CE. A small assemblage of vertebrate fossils from Spring Bay, Barbados. J Barbados Mus Hist Soc 1964; 31: 11-22.

[27] Wing ES. In: Drewett PL, Ed. Prehistoric settlements in the caribbean. London: Archetype Publications for the Barbados Museum and Historical Society 2000; pp. 147-53.

[28] Schomburgk RH. The history of Barbados. London: Frank Cass and Company 1848.

[29] Hohman EP. The American whaleman: A study of life and labor in the whaling industry. New York: Longmans, Green and Co. 1928.

[30] Murphy RC. Logbook for Grace. New York: MacMillan 1947; p13, 52 .

[31] Rathjen WF, Sullivan JR. West Indies whaling. Sea Frontiers 1970; 10: 130-7.

[32] Caldwell DK, Caldwell MC. Porpoise fisheries in the southern Caribbean - present utilizations and future potentials. In: Higman JB, Ed. Proceedings of the $23^{\text {rd }}$ Annual Session of the Gulf and Caribbean Fisheries Institute; 1971; Coral Gables, FL: Rosenstiel School of Marine and Atmospheric Science 1971; pp. 195-206.
[33] Adams JE. Last of the Caribbean whalemen. Nat Hist 1994; 103 : 64-72.

[34] Reeves RR, Swartz SL, Wetmore S, Clapham PJ. Historical occurrence and distribution of humpback whales in the eastern and southern Caribbean Sea, based on data from American whaling logbooks. J Cetacean Res Manage 2001; 3: 117-29.

[35] Brown HH. The sea fisheries of Barbados: a report. Development and Welfare in the West Indies 1942; 1: 18.

[36] Skinner AO. In: Sinckler EG, Ed. The Barbados Handbook, London: Duckworth 1914; pp. 213-4.

[37] Sambon L. West Indian whaling. Empire Rev 1923; 37: 264-7.

[38] Clark AH. In: Goode GB, Ed. The fisheries and fishery industries of the United States. History and methods of the fisheries. Washington, D.C.: U.S. Government Printing Office 1887; Vol. 2(sec 5), pp. 3-218, pp. 214-215.

[39] Adams JE. Historical geography of whaling in Bequia Island, West Indies. Caribbean Stud 1971; 11: 55-74.

[40] Beck HP. In: Jabbour A, Hardin J, Eds. Folklife annual: a publication of the american folklife center at the library of congress. Washington, D.C.: U.S. Government Printing Office 1986; pp. 42-61.

[41] Archer CVH, Fergusson WK. Laws of Barbados. Vol 2. Barbados: Advocate Company 1944.

[42] Bair A. The Barbados fishing industry. Montreal: Dept. of Geography, McGill University 1962. Pub. No. 6.

[43] Yates AW. Bygone Barbados. St. Michael, Barbados: Black Bird Studios 1998.

[44] Excerpt from 'The Liberal' newspaper of Barbados, 19 March 1859. J Barbados Mus Hist Soc 1959; 26: 122.

[45] Smith TD, Reeves RR. Estimating American $19^{\text {th }}$ century catches of humpback whales in the West Indies and Cape Verde Islands. Caribb J Sci 2003; 39: 286-97.

[46] Reeves RR, Jhan JA, Olsen RR, Swartz SL, Smith TD. History of Whaling in Trinidad and Tobago. J Cetacean Res Manage 2001; 3: 45-54.

[47] Smith TD, Reeves RR. Estimating Historical Humpback Whale Removals from the North Atlantic. J Cetacean Res Manage 2002; 4 (Suppl): 242-55.

[48] Richardson BC. Economy and environment in the Caribbean: Barbados and the Windwards in the later 1800s. Barbados: The Press University of the West Indies 1997, Chap. 5.

[49] Swartz SL. Visual and acoustic survey of humpback whales (Megaptera novaeangliae) in the eastern and southern Caribbean Sea: Preliminary findings. Miami: National Oceanic and Atmospheric Administration 2002. NOAA Technical Memorandum NMFS-SEFSC-456.

[50] Smith TD, Allen J, Clapham PJ, et al. An ocean-basin-wide markrecapture study of the North Atlantic humpback whale (Megaptera novaeangliae). Mar Mammal Sci 1999; 15: 1-32.

[51] Starbuck A. History of the American whale fishery. Waltham, MA: Starbuck 1876; p. 200.

[52] Hegarty RB. Returns of whaling vessels sailing from American ports. A continuation of Alexander Starbuck's "History of the American whale fishery" 1876-1928. Bedford, MA: The Old Dartmouth Historical Society and Whaling Museum 1959; p. 10, 45.

[53] Lund JN. Whaling masters and whaling voyages sailing from American ports. A compilation of sources. New Bedford, MA: New Bedford Whaling Museum 2001.

[54] Sherman SC. Whaling logbooks and journals. New York: Garland Publishing 1986.

[55] Stackpole EA. The Sea-Hunters. The New England Whalemen during two centuries 1635-1835. Philadelphia: JB Lippincott 1953; pp. $200,212,242,356,496,524,555,580,582,588,604,606$, $612,626,644,646$.

[56] Reeves RR, Smith TD. A taxonomy of World whaling: operations, eras, and data sources. Woods Hole, MA: National Oceanic and Atmospheric Administration 2003. Northeast Fisheries Science Center Reference Document 03-12.

[57] Castelló HP (Rep). In: Castelló HP, Ed. Anales III reunión de trabajo de especialistas en mamíferos acuáticos de américa del sur. 1988 Jul 25-30; Montevideo, Uruguay 1992; pp. 80-4.

[58] Brown HH. The fisheries of the Windward \& Leeward Islands. Development and welfare in the West Indies 1945; 20.

[59] Romero A. Between war and poverty: whaling in eighteenth century Bermuda. Bermud J Archaeol Marit Hist 2008; 18: 7-32. 
[60] Duerden JE. The marine resources of the British West Indies. W Ind Bull 1901; 2:123-7.

[61] Buissert D, Clark B. A report on the chief monuments of the Turk and Caicos islands from a survey made in 1970's. Bermuda Hist Q 1974; 31: 90-2.
[62] Price WS. Whaling in the Caribbean: Historical Perspective and Update. Rep Int Whal Commn 1985; 35: 413-20.

(c) Romero and Creswell; Licensee Bentham Open.

This is an open access article licensed under the terms of the Creative Commons Attribution Non-Commercial License (http://creativecommons.org/licenses/by-nc/3.0/) which permits unrestricted, non-commercial use, distribution and reproduction in any medium, provided the work is properly cited. 